\title{
Support Library Legislation Day
}

Mark your calendars for the 27th Annual National Library Legislative Day to be held in Washington, D.C. on April 30 and May 1, 2001. This event is sponsored by ALA and other concerned organizations to raise awareness about the importance of federal funding for libraries.

These two days are significant to academic librarians because they provide a venue for librarians to meet with their congressional representatives and to explain how their actions and policy decisions affect academic institutions and their librar ies. Considering the rapid changes that are occurring in our libraries due to evolving information technology, we must keep our representatives informed and educated of the inplications of information policy on academic libraries.

On Monday, you will be briefed on general legislative issues important to libraries. And ACRL will sponsor an activity designed to brief you on issues particularly important to academic librarians.

For the past two years, the ACRL Board has sponsored a legislative luncheon with speakers and panelists for academic librarians who are participating in the Legislative Day activities. The 2001 ACRL luncheon and discussion will be held on Monday, April 30, and will focus on three important legislative issues; 1$)$ reauthorization of the Library Services and Technology Act (LSTA), 2) the Uniform Computer Information Transactions Act (UCITA), and 3) the Children's Internet Protection Act (CIPA). Later in the day you may caucus with your state delegation.

On Tuesday, you will join your state delegation and visit your congressional representatives, delivering your messages about library issues. Past experience of other academic librarians indicates that you may want to arrive in D.C. on Sunday to be ready for the full day of activities on Monday.

ALA has set aside a block of rooms at the Holiday Inn on The Hill. Call (800) 6381116 and ask for the ALA rate. For more information about registration, access the Legislative Day Web site at http://www.ala. org/washoff/legday.html. You will also want to check with your state association legislative committee about teaming with them for visits to the congressional offices. If you plan to attend, contact Shannon Cary. - Shannon Cary, ACRL director of research and special initiatives, scary@ala.org

\section{Chronicle ad salutes libraries}

Watch for a full-page announcement in a forthcoming issue of the Chronicle of Higher Education congratulating our 2001 winners of the Excellence in Academic Libraries Award, sponsored by Blackwell's Book Service.

This announcement is part of a media campaign approved by the ACRL Board to underscore to members of the higher education community the continued vitality and value of acadenic libraries.

The winners of this award exemplify the exceptional manner through which their library staffs collaborated to anticipate and respond in creative and inno- vate ways to the information needs of their institutions.

Winners for 2001 are:

- Austin Community College (community college division)

- Earlham College (college division); and

- University of Arizona (university division)

When it appears, please bring this announcement to the attention of presidents, provosts, deans, faculty, and other appropriate individuals and groups at your institution.

In the near future, your winning library may also be recognized nationally through an Excellence in Academic Libtaries Award! 